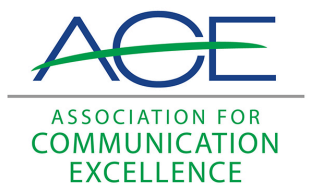

Journal of Applied Communications

\title{
Improving Technical and Bureaucratic Writing; Science Magazines: The Second Wave Rolls In; Extraordinary Science Essays of the Past Half Century; Update: Technical Communication at Rensselaer
}

Dot Sparer

Follow this and additional works at: https://newprairiepress.org/jac cc) (ㅇ)

This work is licensed under a Creative Commons Attribution-Noncommercial-Share Alike 4.0 License.

\section{Recommended Citation}

Sparer, Dot (1982) "Improving Technical and Bureaucratic Writing; Science Magazines: The Second Wave Rolls In; Extraordinary Science Essays of the Past Half Century; Update: Technical Communication at Rensselaer," Journal of Applied Communications: Vol. 65: Iss. 3. https://doi.org/10.4148/1051-0834.1762

This Review is brought to you for free and open access by New Prairie Press. It has been accepted for inclusion in Journal of Applied Communications by an authorized administrator of New Prairie Press. For more information, please contact cads@k-state.edu. 


\title{
Improving Technical and Bureaucratic Writing; Science Magazines: The Second Wave Rolls In; Extraordinary Science Essays of the Past Half Century; Update: Technical Communication at Rensselaer
}

\author{
Abstract \\ Reviews of "Improving Technical and Bureaucratic Writing," by Mohan R. Limaye; "Science Magazines: The \\ Second Wave Rolls In," in Science; "Extraordinary Science Essays of the Past Half Century," by Richard \\ Conniff; "Update: Technical Communication at Rensselaer," in Journal of Technical Writing and \\ Communication.
}




\section{Reviews}

"Improving Technical and Bureaucratic Writing," by Mohan R. Limaye, University of Texas, in Journal of Technical Writing and Communication Vol. 11 (1), 1981, p.23.

Unfortunately the title of the article is a self-fulfilling prophecy. The author's writing is pretty technical and bureaucratic, although he does have some good advice. I didn't think we needed to be reminded to use commas and modifiers in their proper places, or to use appropriate prepositions. But most of us can benefit, I think, from his other two reminders: to keep subject and verb as close together as possible, and to present information about an event in chronological order.

Keeping subject and verb close together is particularly important, Limaye says, because many researchers claim the short-term memory can handle only five-or-so words. This means your mind is likely to lose track of the subject before you arrive at the verb in sentences like this one:

As a result of a recent information request from the Legislative Audit Bureau, the data relevant to AFDC-U cases that had been closed because the client's income exceeded state eligibility limits, was analyzed in an effort to predict the effects of proposed legislation.

He cites an even more depressing example of a government memo to illustrate the idea that events must be presented in the same order they happened to prevent the reader's mind from zigzagging back and forth until he or she is totally lost.

Finally, Limaye leaves us with what seems like a useful bibliography, plus this reminder: "The first principle of readability is that the writer of expository prose sweats so that the reader doesn't have to." Amen. 
“Science Magazines: The Second Wave Rolls In," Science, Vol. 215, 15 January 1982

"There are literally thousands of business magazines," Science reports, "and the same thing is happening in the world of science publishing." This article proceeds to tell us about the thinking and funding behind six publications launched recently or about to be born.

"The splash made by the first wave of new science publications has lured several entrepreneurs into this newly discovered consumer market," we are told. But the article also points out that increased postage and decreased taxes are making things tough for science magazine publishers. (A lower tax rate means people with money are not as likely to invest big bucks in a new magazine as a tax shelter.)

In any case, if you'd like a quick tour of the science magazine boom in general-as well as Technology, High Technology, Technology Illustrated, American Health, Science Week, Current Controversy, and Nature in particular-this article will probably tell you most of what you wanted to know.

\section{"Extraordinary Science Essays of the Past Half Century," by Richard Conniff, Science Digest, December 1981, p. 110}

"The Man of Science appears to be the only man who has something to say just now-and the only man who does not know how to say it," Conniff tells us by way of introduction to a readable, useful compilation of books by scientists who have The Big View of science and life in general, and who have translated this perspective into thoughtful, charming essays.

Instead of the typical scientific writing, which Conniff characterizes as "fragmented, ultraspecialized, [and] jargon-riddled," these essayists produce "another kind of scientific writing, one that unifies, puts the facts into a coherent order, coaches them in human terms."

If you agree with Conniff that often "what is good for science is bad for the reader," you may want to take his recommendations about books that "have something to teach us, not only about science but also about words, literature, and civilization." 

Rensselaer," Journal of Technical Writing and Communication, Vol. 11 (2), 1981, p. 175

This news update from Rensselaer Polytechnic Institute in Troy, New York, reports a new Ph.D. program in technical communication, a plain language project, and a computerized bibliography of technical communication literature.

The newly instituted technical communication track in Rensselaer's Ph.D. program is designed to produce (among others) writers who can handle highly technical and scientific information, as well as administrators for PR offices that handle scientific information.

The plain language project is designed to be part of a national plain language movement (hallalujah!) mandated in New York state and some federal legislation. Apparently former President Carter mandated plain language in federal regulations while he was in office, and a bill was enacted by Congress in December 1980 calling for sweeping revision of the writing done by federal employees, as well as organizations that deal with the feds. (It's known as the Paperwork Reduction Act of 1980.)

Rensselaer's Department of Language, Literature, and Communication is collecting all information available on this subject from leaders in the national plain language movement. The department's goal is to make consultants available to business, government, industry, and higher education "in a systematic way and to increase knowledge of the techniques of plain language."

The purpose of Rensselaer's bibliography project is to put together a database about technical communication which would be available on line in a form suitable for interactive searching and researching. The bibliography will be updated automatically and will be monitored by a panel of experts in various aspects of technical communication.

Dot Sparer University of Georgia 
Journal of Applied Communications, Vol. 65, Iss. 3 [1982], Art. 6

https://newprairiepress.org/jac/vol65/iss3/6

DOI: $10.4148 / 1051-0834.1762$ 